\title{
Community Nurse Assessment of Cardiovascular Behavioural Risk Factors - A Qualitative Analysis within the CroHort Study
}

\author{
Adriana Andrić ${ }^{1}$ and Silvije Vuletić ${ }^{2}$ \\ ${ }^{1}$ Agency for Medicinal Products and Medical Devices, Zagreb, Croatia \\ 2 University of Zagreb, School of Medicine, »Andrija Štampar« School of Public Health, Croatia
}

\begin{abstract}
A B S T R A C T
The aim of our study was to identify major determinants of cardiovascular behavioural risk factors among subjects at increased risk of cardiovascular disease (CVD). The data for the qualitative analysis were obtained from the Croatian Adult Health Cohort Study (CroHort). The data analysis was based on the principles of Grounded Theory. We have generated the concept of an individual in a vicious circle of risky health behaviour, defined by the low level of motivation and unfavourable personal characteristics which in interaction with unsupportive social environment adversely influence one's health behaviour, leading to negative health outcomes that produce negative effects on one's motivation and social environment. Community nurses assessed that the respondents often weren't adequately recognising their CVD risk and were very reluctant about the change in their risky habits. Our results are supported by the quantitative analysis and are complementing other analyses of the cardiovascular risks within the CroHort study.
\end{abstract}

Key words: cardiovascular diseases, health behavior, risk factors, community health nursing, qualitative research, CroHort study

\section{Introduction}

Cardiovascular diseases are the leading cause of death in Croatia ${ }^{1}$.The death rate from cardiovascular diseases in Croatia can be considered rather high for a developed country and is, for example, twice the one for Italy and significantly higher than the one for Slovenia ${ }^{2}$. Diseases of the circulatory system are responsible for a significant shortening of the expected average life span in Croatia ${ }^{3}$.

Given the size of the problem of the cardiovascular morbidity in Croatia, there is a need for relevant information on behavioural risk factors which are related to cardiovascular diseases (CVD). Cardiovascular behavioural risk factors include dietary habits, physical activity, alcohol intake and smoking and are considered a start point in development of interim risk factors for cardiovascular diseases, such as high blood pressure and obesity $^{4}$. The quantitative analysis of behavioural risk factors and their relation to interim risk factors and cardiovascular morbidity was done extensively for Croatian adult population on the data obtained from the Croatian Adult Health Survey (CAHS) conducted in $2003^{4-14}$. Be- sides elucidation of the poor cardiovascular health in Croatia, these analyses were useful for identifying the need for implementation of the intervention on primary and secondary prevention of CVD performed by the community nurse within the re-survey of the 2003 sample, the Croatian Adult Health Cohort Study (CroHort Study) conducted in 2008. The qualitative investigation module within the intervention was another novelty in the re-survey, with the purpose of both facilitation of the CVD risk evaluation within the single intervention and the improvement of the informativeness and usability of the survey itself ${ }^{15-17}$.

The purpose of our study is to complement the quantitative analysis of the cardiovascular behavioural risk factors as well as the analysis of the intervention model of the CroHort Study ${ }^{18,19}$. The aim of our study was to identify and describe the major determinants of cardiovascular behavioural risk factors among respondents who are at increased risk of CVD. 


\section{Subjects and Methods}

This study is a part of the Croatian Adult Health Cohort study (CroHort study) conducted in 2008, a re-survey of the sample from Croatian Adult Health Survey (CAHS) conducted in 2003. CroHort study consisted of respondents who were examined both in 2003 and 2008 and are considered as the single cohort of 3,229 individuals.

Compared with CAHS, CroHort study was further supplemented with the intervention aimed at the prevention of cardiovascular diseases ${ }^{15}$. The intervention was conducted among 1,277 respondents from the CroHort study cohort, who were considered eligible by a community nurse based on nurse's clinical assessment of respondent as being potentially at increased risk of CVD. The enrolment was on voluntary basis and was depending on respondent's willingness to participate as well as on nurse's motivation to perform an additional intervention.

A specifically designed health booklet was used by community nurse as a key tool for the intervention. The health booklet documented the evaluation of respondent's CVD risk factors based on the quantitative measurements and an interview, the assessment of the required preventive interventions with planned targets agreed with respondent, respondent's self-evaluation of motivation for behavioural change, the findings from follow-up visits and a risk evaluation with an epicrisis after one year ${ }^{16,19}$.

The interview was recorded by a community nurse as free text which consisted of cardiovascular risks assessment, assessment of respondent's motivation for potential lifestyle changes and assessment of various factors which are influencing respondent's health behaviour on a broader level, such as respondent's personality, family circumstances, socioeconomic status or availability of health services. The cardiovascular risks assessment included predominantly assessment of behavioural risk factors, e.g. unhealthy diet, physical inactivity and smoking, but the assessment of interim risk factors such as overweight and hypertension was also included, as well as the data on health outcomes, e.g. diabetes, previous episodes of stroke or myocardial infarction. The quantitative analysis of respondents' motivation for change in risk-related behaviour with the analysis of major metabolic syndrome determinants within this sample of 1,277 respondents was described elsewhere ${ }^{18}$.

The final sample which was analysed in our study included the data on the total of 253 respondents. Both authors were involved in the decision on inclusion of respondents in the study, which was made through an iterative process and was discussed at data analysis meetings. At data analysis meetings, the emerging categories were examined for theoretical saturation ${ }^{20,21}$ and the process of inclusion of data on more respondents was repeated until no new data seemed to emerge regarding a category, the category was well developed in terms of its characteristics and dimensions and the relationships among categories were well established and validated.

Community nurses completed the CVD risk assessment section of health booklet to varying levels of detail. CVD risk assessment sections of the health booklet were transcribed and analysed as free text. The coding process has followed the principles of Grounded Theory ${ }^{22}$ and was carried out manually through four phases (open, axial and selective coding and theory generation). During the open coding phase the data was divided into categories; in vivo coding and process coding were used, where applicable ${ }^{23}$. In the axial coding phase categories were specified regarding their characteristics and dimensions. During the selective coding phase the core categories were identified and named according to their content. In the theory generating phase the concept of an individual in a vicious circle of risky health behaviour, defined by the low level of motivation and unfavourable personal characteristics which in interaction with unsupportive social environment adversely influence one's health behaviour, leading to negative health outcomes that in the end produce negative effects on one's motivation and social environment, thus closing the circle.

\section{Results}

The number of respondents in our study by age group, sex and the level of urbanisation is shown in Table 1. Our sample was comprised mostly of middle-aged and elderly individuals, with slightly more women in the sample than men, majority of them living in the urban areas.

The analysis process is shown in Table 2. Based on our analysis we have generated the concept of an individual in a vicious circle of risky health behaviour, defined by the low level of motivation and unfavourable personal characteristics which in interaction with unsupportive social environment adversely influence one's health behaviour, leading to negative health outcomes that in the end produce negative effects on one's motivation and social environment, thus closing the circle. According to the community nurses' assessment, the respondents in our study often weren't adequately recognising their CVD risk and were very reluctant about the change in their risky habits. The majority of the respondents could be considered medically underserved, considering their statements on the use of health services.

TABLE 1

NUMBER OF RESPONDENTS BY AGE GROUP, SEX AND LEVEL OF URBANISATION*

\begin{tabular}{|c|c|c|c|c|c|c|c|}
\hline \multirow{2}{*}{$\begin{array}{l}\text { Age } \\
\text { group }\end{array}$} & \multicolumn{3}{|c|}{ Male } & \multicolumn{3}{|c|}{ Female } & \multirow{2}{*}{ Total } \\
\hline & Urban & Rural & Total & Urban & Rural & Total & \\
\hline$<35$ & 0 & 1 & 1 & 6 & 1 & 8 & 9 \\
\hline $35-64$ & 39 & 10 & 65 & 42 & 9 & 64 & 129 \\
\hline $65+$ & 33 & 9 & 51 & 48 & 3 & 64 & 115 \\
\hline Total & 72 & 20 & 117 & 96 & 13 & 136 & 253 \\
\hline
\end{tabular}

*The data on level of urbanisation is missing for 52 respondents 
TABLE 2

THE ANALYSIS PROCESS IN GENERATION OF THE CONCEPT OF AN INDIVIDUAL IN A VICIOUS CIRCLE OF RISKY HEALTH BEHAVIOUR

Coding phase and description Categories

Initial coding identification of categories

Axial coding specification of characteristics and dimension of a category

Selective coding identification and naming of core categories

Theory generation development of the concept of an individual in a vicious circle of risky health behaviour
General health, risk of CVD, lifestyle, motivation for change, health as priority, physical activity, dietary habits, smoking status, alcohol intake, bodyweight, metabolic risks, psychological stress, availability of health services, social status, income, personality, family influence, family history of CVD, emotional status, social participation

1. General health (good vs. poor general health, capability for self-care)

2. Risk of CVD (high - moderate - low - no risk)

3. Lifestyle (healthy - unhealthy)

4. Motivation for change (high, moderate, low, increasing, decreasing, genuine or not)

5. Health as priority (takes care of/neglects one's health, health literacy, improved one's health behaviour due to CVD or other illness, attitude towards health check-ups, adherence to proscribed therapy)

6. Physical activity (active - inactive, mobility)

7. Dietary habits (regular meals, amount of food, type of foodstuffs)

8. Smoking status (smoker, non-smoker, ex-smoker)

9. Alcohol intake (high - moderate - no intake)

10. Bodyweight (obese - increased body weight - normal body weight - underweight)

11. Metabolic risks (hypertension, hyperlipemia, diabetes)

12. Psychological stress (stressed or not)

13. Availability of health services (visits GP or not)

14. Social status (good vs. poor social status, employed, unemployed, retired, single household)

15. Income (high - adequate - low)

16. Personality (optimistic vs. pessimistic, communicative, outgoing)

17. Family influence (supportive vs. unsupportive)

18. Family history of CVD (family history of CVD vs. no CVD in family history)

19. Emotional status (emotionally well vs. unwell)

20. Social participation (well integrated vs. isolated)

1. Motivation and personal characteristics (categories $4+5+12+16+18+19$ )

2. Social environment (categories $13+14+15+17+20$ )

3. Health-related behaviour (categories $3+6+7+8+9$ )

4. Health outcomes (categories $1+2+10+11$ )

An individual in a vicious circle of risky health behaviour, defined by low level of motivation and unfavourable personal characteristics which in interaction with unsupportive social environment adversely influence one's health behaviour which causes negative health outcomes which in the end produce negative effects on one's motivation and social environment, thus closing the circle.

\section{Motivation and personal characteristics}

The core category 1.Motivation and personal characteristics encompasses the following categories: 4 . Motivation for change, 5. Health as priority, 12. Psychological stress, 16. Personality, 18. Family history of CVD and 19. Emotional status. We have recognized the high motivation for change in individuals who prioritize health as important as a major determinant of responsible health behaviour.

ID 139 (female, aged 59): »The respondent is very interested in preserving her health. She leads a very healthy lifestyle, watches her diet and is very physically active. She doesn't smoke cigarettes, doesn't consume alcohol.
Her body weight is normal, as well as her blood pressure and blood glucose levels."

However, the most common pattern regarding motivation in our study was an individual with low level of motivation which is decreasing over time in respondents who do not prioritize health. Community nurses very often expressed scepticism regarding respondent's honesty in expressing one's motivation.

ID 055 (male, aged 61): »This gentleman lives the day by day. He pays no attention to his health. He hasn't seen his general practitioner (GP) in 10 years. He says that he »doesn't need to go to a GP «. He's not doing anything to reduce his bodyweight. He's seen that with an increase in 
bodyweight there is an increase in blood pressure and he's been informed about the risks of hypertension, but he just doesn't want to change anything at this point."

ID 075 (female, aged 62): »This patient is dissatisfied [with her health status] but she's also not motivated and gives up very easily. She's not honestly motivated for change. She acts like she would like to make a change, but she's not really willing to make an effort to improve her physical activity and diet."

This pattern of low motivation for changing health-related behaviour is found even in situations where there is a supportive family and a favourable social situation. Community nurses very often found these respondents to be very resistant regarding the intervention aimed at reducing their risk of CVD.

ID 117 (female, aged 68): »The respondent lives in a single household, the social situation is optimal. BMI indicates that the patient is overweight. She admits that she isn't paying attention to her diet, even though she's got the absolute opportunity to do so. She would definitely need to cut out snacks from her diet and reduce the intake of fat and carbohydrates. She's even been warned by family members about it [the diet], but she doesn't consider it to be a serious issue. She doesn't want to dwell over it. She wants to reduce her bodyweight and to adhere to diet regimen, but her will isn't strong and she often deviates from the diet and consumes cakes and sweets. She's hypertensive, but she isn't taking her medicines regularly so she wouldn't have to visit her GP too frequently.«

The respondents who suffer from mental illnesses are in very unfavourable position regarding the prevention of CVD. Their mental status vastly influences their social status and vice versa, negatively influencing their health-related behaviour and subsequently their health outcomes. They express very little power, if any, to change their situation.

ID 130 (female, aged 74): »Due to her illness [schizophrenia] and the medicines she uses, this patient's level of physical activity is very low ([and subsequently] she's fat). She is very lonely. She's very resigned because of her illness and her social situation. Her diet is very monotonous due to low income. She's taking her BP medicines regularly, so her $\mathrm{BP}$ level is normal. Her motivation for changing her habits is non-existing. Her GP, community nurse and social worker are involved, but that isn't changing her situation. She's lacking the support from her family: her husband is ill and their children are not talking to them."

The health literacy issue was frequently mentioned in the nurses' observations. Health literacy was most commonly described as a core aspect of a respondent's motivation for responsible health-related behaviour and was more frequently stated when describing respondents with higher level of education.

ID 182 (male, aged 77): »The patients lives with his wife, they don't have children. His dietary habits are appropriate, he's enough physically active and relatively healthy considering his age. He is an intellectual and he's health literate. [This patient's bodyweight, blood pressure levels, blood glucose levels in fasting state, blood cholesterol levels and blood triglyceride levels are normal.]《

The respondents whose level of health literacy was considered to be low often showed very modest interest in the consultation and a low level of comprehension of the conversation and the questions that were asked.

ID 110 (female, aged 64): "Extremely poor social and financial situation. The patient lives in the rural area where health literacy is non-existing. One gets the impression that respondent doesn't understand at least half of the questions and despite my attempts to explain, she responds randomly, seeking advice from her son and me myself. She doesn't understand the seriousness of her CVD risks (hypertension, physical inactivity, alcohol intake, poor hygienic conditions).«

\section{Social environment}

The core category 2 . Social environment encompasses the following categories: 13 . Availability of health services, 14. Social status, 15. Income, 17. Family influence, 20. Social participation. This core category represents the individual's ability to live productive and meaningful life and is mainly defined by the level of income and presence or absence of support from one's family. A significant number of respondents in our study were found to have a low income, often living in single household. Community nurse assessments of these respondents described very clearly the strength of the influence of social deprivation on respondents, their health-related behaviour and health outcomes.

ID 068 (female, aged 58): »The respondent lives in a single household, her income is low $(880 \mathrm{kn})$. She's neglected by her children, they rarely visit her and they aren't helping her at all. Her general health is poor; she often experiences headaches [the patient has previously undergone a neurosurgical procedure of an aneurism]. She's lonely, depressed and apathetic. She's doing her housework with pain all over her body which limits her mobility, she often feels dizzy and fells. The patient is obese. Her GP's office is 2 kilometres away but she hasn't got anyone to take her there (sometimes she succeeds to talk her sons into it). She's not taking her medicines regularly [This respondent suffers from hypertension, diabetes and hyperlipemia.]."

ID 046 (female, aged 31): "Low social status (5 household members, 1 income) limits the possibility of changing the lifestyle, and that causes psychological stress. Her diet is unhealthy and she smokes cigarettes."

The unavailability of health services as well as other social services was frequently described. The relation between low income and poor diet was often stated.

ID 111 (male, aged 62): »The patient lives in very difficult socio-economic situation. He's got no monetary income and his bare existence is compromised. He lives barely from agriculture. He's overweight, in food prepa- 
ration he uses pork fat and he consumes larger amounts of bread. He doesn't have financial opportunity to choose groceries. He almost always adds salt to food without previous tasting. He doesn't visit the GP because he doesn't have a health insurance [This respondent was found to be hypertensive and hyperlipemic. He has managed to obtain the health insurance and was introduced to the necessary therapy.].«

\section{Health-related behaviour}

The core category 3 . Health-related behaviour encompasses following categories: 3 . Lifestyle, 6 . Physical activity, 7. Dietary habits, 8. Smoking status and 9. Alcohol intake. The health-related behaviour of respondents in our study was shown to be strongly determined by low level of motivation and low position of one's health in ranking life priorities. The middle-aged working respondents often give priority to other issues, trying to balance the demands of everyday life. Some of the respondents verbalize very clearly their struggle in getting their priorities straight, while other don't seem to care as long as they don't have major health issues.

ID 159 (female, aged 30): »This lady is a very sweet young mother and a wife. As a nurse, she works a lot, including shift work. They live in a rented flat, the lady, her husband and their child. They both have high school diplomas. The lady's income is regular, but her husband's isn't. The patient had previously undergone thyroid surgery, and now she is taking substitutive therapy and gets her check-ups regularly. She is a smoker. She would like it if she wouldn't have to work in shifts because then she could have her meals regularly and she could sleep more what would do good for her thyroid [status], but instead she works nightshifts so she could spend her days with her child, because her husband works all day long. She's aware of everything, her health risk, but she just cannot organize things differently because this is a vicious circle. She shows interest and motivation for the intervention, she knows everything about what she would need to do, but her life just takes its own direction and she cannot help herself. Regarding smoking, she says it depends on the day, sometimes she is smoking less, sometimes more."

ID 027 (male, aged 40): »The patient is aware of his risks and his behaviour but this is something that he verbalizes only, he's not motivated to change his behaviour because he doesn't have major [health] issues for now, except the psychological stress related to his job. The respondent works as a manager in an insurance company and he's not able to take some time for the intervention."

In our study we have not been able to identify a clear pattern regarding the motivation and the subsequent change of risky behaviour for different cardiovascular risks. However, it seems that there is a tendency of verbalizing higher motivation for changes which are not expected to require a strong effort, e.g. taking medicines for reduction in blood pressure, blood glucose or blood lipid levels. Among above mentioned risk factors the motivation for regulation of hypertension seemed to be the strongest. The process of consultations was often described as a trade-off between the nurse and the respondent and a change in symptoms of metabolic syndrome seemed to be perceived as »best buy « by respondents. They have also shown low level of motivation for quitting smoking and reducing bodyweight and were very reluctant regarding the change in dietary habits or the increase in physical activity.

ID 097 (male, aged 73): »He eats everything, his meals are irregular. He's aware that he needs to reduce the intake of carbohydrates [the respondent had increased blood glucose level in fasting state on several occasions] and fat, but he hasn't got the will to do so. However, he goes to blood glucose level and blood pressure level check-ups on a weekly basis. He continuously consumes sweets and he wants no limitations. He says his life is difficult enough anyway."

ID 026 (male, aged 68): »He isn't motivated for a change in his lifestyle. He is smoking, his alcohol consumption is moderate. Occasionally he consumes sweets [diabetic patient]. He should reduce his bodyweight, reduce the intake of fat, cut out the intake of sweets, and reduce the smoking and the intake of alcohol. He should increase his physical activity. He tried to follow the instructions for a brief time, but he gave up, he said it was too difficult."

Even though it seems to be the change which is most difficult to achieve, along with the change in one's dietary habits, the increase in physical activity seemed to be more easily achieved in individuals with previous positive experiences regarding physical activity. The assessment of physical activity often included the statement on limited mobility due to illness.

ID 188 (male, aged 73): "... The patient is of limited mobility due to arm and leg fracture following a fall that occurred a few years ago. At that time the patient underwent the physical therapy and he felt much better. Now he wishes to attend medical-gymnastics which is being held at local community's facilities. «

The process of behavioural change is slow and with an uncertain outcome. In the majority of cases the progress is modest and accomplished after a community nurse has put a lot of continuous effort into it. In other cases, in patients who are initially highly motivated and have a supportive environment, the goals seem to be achieved much painlessly.

ID 227 (female, aged 59): »The patient is extremely obese and physically inactive. She suffers from hypertension, diabetes and hyperlipemia. She accepts advice regarding weight loss reluctantly. She isn't motivated for an increase in physical activity. Her dietary habits are unhealthy, she eats a lot, including a lot of fat and sugar... She's starting to realize the importance of physical activity so she's trying to walk briskly at least every other day for 30 minutes. She also does light exercises while watching television. «

ID 249 (female, aged 37): „She's a moderate smoker (3-5 cigarettes a day). She's often tense. Her diet is well 
balanced; she eats a lot of fruit. She's physically active. [The epicrisis at the end of the intervention included the following statement: The patient's health-related behaviour was appropriate to begin with, and in the meantime she has quitted smoking.]."

\section{Health outcomes}

The core category 4. Health outcomes encompasses following categories: 1 . General health, 2. Risk of CVD, 10. Bodyweight and 11. Metabolic risks. The degree of seriousness of health outcomes varies in our study. The assessment of health outcomes often included remarks on general health and functional ability of a CVD patient. The presence of the components of the metabolic syndrome (hypertension, diabetes, hyperlipemia) was often stated as a synonym for risk of CVD, while the overweight, even though frequently recognized, wasn't given importance as big as one given to above mentioned disorders. The influence of health outcomes on one's motivation, personal characteristics and social environment and subsequently on one's health-related behaviour is double-natured. In majority of the cases, metabolic risks and increased bodyweight seemed not to have a positive impact on one's motivation for change nor did it make respondents willing to prioritize health. On the contrary, in majority of cases it seems almost like the awareness of these risks overgrows itself, becoming a part of individual's identity which makes one even weaker to make a change, while health deterioration slowly takes its toll over one's lifetime.

ID 090 (female, aged 71): »The social situation is bad, the family relations are disturbed. Due to her financial situation the patient has no motive at all to change her lifestyle, but also due to her belief that hypertension and increased bodyweight do not represent a risk of developing CVD. She's not interested in the intervention and she reckons the change is not needed."

ID 096 (female, aged 59): »The patient states she's adhering to dietary regimen due to hypertension and hyperlipemia. She is physically active on a daily basis (she rides a bike). She is taking prescribed medicines regularly. She doesn't smoke nor consumes alcohol. [The epicrisis at the end of the intervention included the following: The respondent claims that she's adhering to the lipid-reduction diet, but she has clearly gained weight and she hasn't went to a blood lipid level check-up for a longer period of time.]. «

A positive influence of health outcomes on one's risk behaviour seemed to occur more frequently if the health outcome in question was more severe, given that social environment is supportive enough.

ID 071 (female, aged 65): »The patient was hospitalized due to transitory ischemic attack, after which the diabetes was diagnosed. She was treated with insulin. The patient is very motivated and disciplined about applying the recommended health measures. Religion has a large impact on her behaviour. Her husband is gladly involved in the mentioned activities [later on this patient was in- troduced to oral diabetes therapy and insulin was discontinued].«

However, in respondents who are strongly socially deprived their health-related choices are not on their own behalf, sometimes even if their own life is in question.

ID 231 (female, aged 57): »The patient lives with her unemployed husband and their son who is a college student, so she is the only one in the household who makes an income. Her dietary habits are bad; she doesn't exercise, she smokes a lot and refuses to quit, drinks coffee a lot and is stressed out; she also suffers from psoriasis. She was admitted to hospital due to myocardial infarction but she has refused to remain hospitalized because of her family's financial situation. Prior to the hospitalization she was taking her blood pressure lowering medicines regularly, but she was refusing insulin therapy even though she was diagnosed with diabetes several years ago. [The epicrisis at the end of the intervention included the following statement: She's not adhering to the given recommendations and she refuses any advice. The thumb on her left feet began turning blue (gangrene). She refuses insulin. She smokes a lot. She is health illiterate.]«

ID 077 (male, aged 69): »The patient hasn't visited a GP office in 30 years, but now he pleads for another visit because of the pain in his right foot. He smokes a lot (a pack to two packs of cigarettes a day), he drinks a lot of coffee and his diet is poor. He doesn't want to change anything. [Observation from the second follow-up visit to this respondent: The patient is depressive because of the possibility of amputation of his leg due to gangrene. He barely moves because of the pain, but he doesn't want to change his state nor his habits. Observation from the third follow-up visit: The patient's leg was amputated in the thigh. He wants to be more physically active, but he doesn't want to reduce his smoking and he doesn't eat regularly. The epicrisis included the following observation: The only success is that the patient now eats regularly, he is willing to measure blood glucose levels and blood pressure and he is taking the medicines prescribed by the doctor regularly.]《

\section{Discussion}

Based on our study we were able to identify factors which determine health-related behaviour of individuals who are at increased risk of CVD. The unfavourable factors in the social environment elicit the undesirable health-related behaviour in the individuals who are characterised by low level of motivation and unfavourable personal characteristics, leading towards the negative health outcomes which adversely affect one's motivation and social environment. The quantitative analysis of the patients' risk self-assessment, their motivation for chan ges in main determinants of the metabolic syndrome and the community nursing intervention on reduction in cardiovascular risks, carried out within the CroHort study ${ }^{18}$, strongly supports our results. 
Our results suggest a strong negative influence of an unsupportive social environment on individual's health-related behaviour and subsequent health outcomes. The respondent in our study often were medically underserved and socially deprived which made them less capable to become actively involved in making changes to their health.

Our findings are comparable with other unfavourable patterns of risk-related behaviour reported in different studies globally. It is generally considered that individuals who are at higher risk of CVD tend to have a lower perception of their risk, compared to the individuals whose CVD risk objectively is lower. In a study aimed at identification of barriers for primary prevention it has been shown that patients' risk perception tends to be unrealistic and dichotomous, accompanied with the lack of understanding of CVD prevention which therefore requires highly individualized high-risk approach to be explained to the patients ${ }^{24}$. The same authors have found that men are more likely to perceive their CVD risk inappropriately when compared to women; patients with diabetes were also more likely to incorrectly underestimate their risk ${ }^{25}$. Another study of CVD knowledge and risk perception among underserved individuals at increased risk of CVD has found that women and urban population are more likely to perceive their risk to be higher and to be more knowledgeable about CVD, when compared to men and rural population, respectively ${ }^{26}$. In our study we weren't able to identify differences in the risk-related behaviour according to respondent's gender and origin, i.e. differences between rural and urban population. Since the enrolment in the intervention based on nurse's clinical assessment of respondent as being potentially at increased risk of CVD was on voluntary basis, i.e. depending on respondent's willingness to participate, and was also depending on nurse's motivation to perform an additional intervention, it would be plausible to assume that most-at-risk subjects were enrolled in our study, therefore making the identification of differences according to gender and residency more difficult. This also represents the major limitation of our study since it limits the generalizability of the results.

Nurse-led interventions aimed at cardiovascular risk management have been shown to be successfully implemented in different settings, including the medically underserved populations ${ }^{27-30}$. Nevertheless, it would not be reasonable to expect short-term interventions to show long-term effects on behaviour change ${ }^{31,32}$. In a study aimed at exploring motivational aspects related to potential lifestyle changes among patients at increased risk of CVD following preventive consultation, the ambivalence related to potential lifestyle changes was found to be the core motivational aspect ${ }^{33}$. Some authors suggest that practice nurses are more successful in providing CVD interventions and provide more lifestyle interventions compared to general practitioners, assuming the availability of national guideline on cardiovascular prevention ${ }^{34}$. How- ever, the community nurses included in the conduction of our intervention reported the lack of specific training and education in planning and implementation of individualised interventions and counselling ${ }^{19}$. Besides the education of health system workforce, when planning an intervention aimed at reducing CVD risk and associated outcomes, an appropriate consideration should be given to the unique context (which includes people, place and time), since the simple replication of an intervention which was successfully implemented in other setting, such as North Karelia project, might undermine the success of the new intervention ${ }^{35}$. The influence of health system on health-related behaviour change was thoroughly explored, suggesting that an 'effective' health system needs to contain elements that are stable and structured (e.g. the resources) while at the same time it also needs to react and evolve to recognise and meet the needs of its client groups ${ }^{36}$. Beyond the efforts invested in building up the health system which is effective in achieving the health-related behaviour change, the education and mobilization of the lay public as well as the involvement of civic and health care leadership supported with appropriate policies and legislation is needed to meet the challenges of change in lifestyle of the population ${ }^{37}$.

There have been recent calls for models of primordial prevention of CVD in $\mathrm{USA}^{38}$ and India ${ }^{39}$ aimed at reducing the onset of the risk factors known to predispose humans to CVD. The results obtained from the Whitehall study suggest that the primordial intervention aimed at reducing socioeconomic inequalities of coronary disease mortality shows some additional benefit if compared with successfully implemented best-practice interventions ${ }^{40}$.

To conclude, our results on cardiovascular behavioural risk factors complement other analyses of the cardiovascular risks performed within the CAHS and the CroHort studies. The data obtained from the CroHort study helps to enhance the knowledge about and the characterization of the burden of cardiovascular disease in Croatia. Until now, this knowledge was based only on data from vital statistics and sporadic projects and studies, which still makes a substantial body of evidence for policy makers, at least if compared to data available in some neighbouring countries ${ }^{41}$. However, the data from the CAHS and the CroHort studies represent a wide basis of information for decision making in the creating of the health policy and the development of the comprehensive national programme of the prevention of the cardiovascular diseases, which can now be tailored according to the needs of the Croatian population.

\section{Acknowledgements}

This article was prepared as a part of scientific project »Regionalism of cardiovascular behavioural risk factors model of intervention « (108-1080135-0264) supported by Ministry of Science, Education and Sport of the Republic of Croatia. 


\section{R E F E R E N C E S}

1. BAKLAIĆ Ž, DEČKOVIĆ-VUKRES V, KUZMAN M, Croatian Health Service Yearbook 2009 (Croatian National Institute of Public Health, Zagreb, 2010). - 2. WHO Global Infobase, Estimated Age Standardized Death Rate (per 100,000), Cardiovascular diseases, Both Sexes, 2004, WHO European Region, accessed 02.07.2011. Available from: URL: https:/ apps.who.int/infobase/Comparisons.aspx. - 3. LIPOVŠĆAK M, Potential years of life lost in the Republic of Croatia during 2000.-2004. (The Croatian Bureau of Statistics, Zagreb, 2011). - 4. VULETIC S, KERN J, BRBOROVIĆ O, VUKUŠIĆ T, Coll Antropol, 33 (2009) 131. — 5. DOKO JELINIĆ J, PUCARIN-CVETKOVIĆ J, NOLA IA, SENTA A, MILOŠEVIĆ M, KERN J, Coll Antropol, 33 (2009) 31. - 6. MILOŠEVIĆ M, GOLUBIĆ R, MUSTAJBEGOVIĆ J, DOKO JELINIĆ J, JANEV HOLCER N, KERN J, Coll Antropol, 33 (2009) 35. - 7. BENČEVIĆ-STRIEHL H, MALATESTINIĆ D, VULETIĆ S, Coll Antropol, 33 (2009) 39. - 8. SAMARDŽIĆ S, VULETIĆ MAVRINAC G, PRLIĆ A, Coll Antropol, 33 (2009) 43. - 9 . SAMARDŽIĆ S, PRISTAŠ I, VULETIĆ MAVRINAC G, Coll Antropol, 33 (2009) 61. - 10. MUSIĆ MILANOVIĆ S, IVIČEVIĆ UHERNIK A, FIŠTER K, Coll Antropol, 33 (2009) 67 - 11. BRBOROVIĆ O, VUKUŠIĆ RUKAVINA T, PAVLEKOVIĆ G, DŽAKULA A, ŠOGORIĆ S, VULETIĆ S, Coll Antropol, 33 (2009) 93. - 12. VULETIĆ MAVRINAC G, MASLIĆ SERŠIĆ D, MUJKIĆ A, Coll Antropol, 33 (2009) 99. — 13. SAMARDŽIĆ S, VULETIĆ MAVRINAC G, Coll Antropol, 33 (2009) 107. — 14. MAGAS̆ S, POLJIČANIN T, ŠEKERIJA M, AJDUKOVIĆ D, METELKO Ž, CAR N, KERN J, Coll Antropol, 33 (2009) 115. - 15. VULETIĆ S, POLAŠEK O, KERN J, STRNAD M, BAKLAIĆ Ž, Coll Antropol, 33 (2009) 3. — 16 PAVIĆ J, ŽUPANIĆ M, MUSIĆ MILANOVIĆ S, FIŚTER K, Coll Antropol, 33 (2009) 81. - 17. SANDELOWSKI M, Res Nurs Health, 23 (2000) 246 - 18. POLJIČANIN T, ŠEKERIJA M, BORAS J, CANECKI-VARŽIĆ S, METELKO Ž, KERN J, VULETIĆ S, Coll Antropol, 36 Suppl 1 (2012) 35 - 19. DŽAKULA A, IVEZIĆ J, ŽILIĆ M, CRNICA V, BANDER I, JANEV HOLCER N, ŠOGORIĆ S, PAVIĆ J, ŽUPANIĆ M, VULETIĆ S, Coll Antropol 36, Suppl 1 (2012) 21. - 20. STRAUSS A, CORBIN J, Basics of Qualitative Research (SAGE Publications, London, Thousand Oaks, New Delhi, 1998). - 21. GLASER BG, Theoretical Sensitivity: Advances in the methodology of Grounded Theory (Sociology Press, Mill Valley,1978) - 22. GLASER BG, STRAUSS AL, The discovery of grounded theory: strategies for qualitative research, (Aldine Publishing, Chicago, 1967). -
23. SALDAÑA J, The Coding Manual for Qualitative Researchers (SAGE Publications, London, Thousand Oaks, New Delhi 2009). - 24. VAN STEENKISTE B, VAN DER WEIJDEN T, TIMMERMANS D, VAES J, STOFFERS J, GROL R, Patient Educ Couns, 55 (2004) 301. - 25. VAN DER WEIJDEN T, VAN STEENKISTE B, STOFFERS HE, TIMMERMANS DR, GROL R, Med Decis Making, 27 (2007) 754. — 26. HOMKO CJ, SANTAMORE WP, ZAMORA L, SHIRK G, GAUGHAN J, CROSS R, KASHEM A, PETERSEN S, BOVE AA, J Cardiovasc Nurs, 23 (2008) 332. - 27. MENG H, WAMSLEY BR, EGGERT GM, VAN NOSTRAND JF, J Rural Health, 23 (2007) 322. - 28. BOVE AA, SANTAMORE WP, HOMKO C, KASHEM A, CROSS R, MCCONNELL TR, SHIRK G, MENAPACE F, Am Heart J, 161 (2011) 351 - 29. WISTER A, LOEWEN N, KENNEDY-SYMONDS H, MCGOWAN B, MCCOY B, SINGER J, CMAJ, 177 (2007) 859. - 30. HALCOMB E, MOUJALLI S, GRIFFITHS R, DAVIDSON P, Int J Evid Based Healthc, 5 (2007) 269. 31. BACH NIELSEN KD, DYHR L, LAURITZEN T, MALTERUD K, Scand J Prim Health Care, 23 (2005) 233. - 32. KOELEWIJN-VAN LOON MS, VAN DER WEIJDEN T, RONDA G, VAN STEENKISTE B, WINKENS B, ELWYN G, GROL R, Prev Med, 50 (2010) 35. - 33. KEHLER D, CHRISTENSEN B, LAURITZEN T, CHRISTENSEN MB, EDWARDS A, RISØR MB, BMC Fam Pract, 9 (2008) 50. - 34. VOOGDT-PRUIS HR, VAN REE JW, GORGELS AP, BEUSMANS GH, Int J Nurs Stud, 48 (2011) 798. - 35. MCLAREN L, GHALI LM, LORENZETTI D, ROCK M, Health Educ Res, 22 (2007) 414. - 36. SWANN C, CARMONA C, RYAN M, RAYNOR M, BARI“ E, DUNSDON S, HUNTLEY J, KELLY MP, Health systems and health-related behaviour change: a review of primary and secondary evidence, accessed 06 . 06.2011. Available from: URL: http://www.nice.org.uk/ media/ 0E6/62/ SpecialReportHealthSystemsAndHealthRelatedBehaviour ChaSpe. pdf. 37. DAGOGO-JACK S, EGBUONU N, EDEOGA C, Med Princ Pract 19 (2010) 167. - 38. KONES R, Ther Adv Cardiovasc Dis, 5 (2011) 61. - 39. GUPTA R, GUPTHA S, JOSHI R, XAVIER D, Health Res Policy Syst, 9 (2011) 8. - 40. KIVIMÄKI M, SHIPLEY MJ, FERRIE JE, SINGH-MANOUX A, BATTY GD, CHANDOLA T, MARMOT MG, SMITH GD, Lancet, 372 (2008) 1648. - 41. VASILJ I, PILAV A, MASLOV B, POLASEK O, Coll Antropol, 33 (2009) 185.

\section{A. Andric}

Agency for Medicinal Products and Medical Devices, Ksaverska cesta 4, 10000 Zagreb, Croatia e-mail: adriana.andric@halmed.hr

\section{OCJENA PATRONAŽNE SLUŽBE KARDIOVASKULARNIH PONAŠAJNIH ČIMBENIKA RIZIKA - KVALITATIVNA ANALIZA HRVATSKE KOHORTNE STUDIJE KARDIOVASKULARNOG ZDRAVLJA}

\section{S A Ž E T A K}

Cilj ovog rada bio je identificirati i opisati glavne odrednice kardiovaskularnih ponašajnih čimbenika rizika u ispitanika pod povećanim rizikom od kardiovaskularnih bolesti. Podaci za kvalitativnu analizu kardiovaskularnih ponašajnih čimbenika rizika dobiveni su iz zdravstvene knjižice dizajnirane za zdravstvenu intervenciju patronažne sestre, koja je provedena u sklopu Hrvatske kohortne studije kardiovaskularnog zdravlja (CroHort). Analiza se temeljila na načelima utemeljene teorije i provedena je kroz četiri faze (otvoreno, aksijalno i selektivno kodiranje i razvoj teorije). $\mathrm{Na}$ temelju naše analize razvijen je koncept pojedinca u začaranom krugu rizičnog zdravstvenog ponašanja, koji je definiran niskom razinom motivacije i nepovoljnim osobnim obilježjima koja u međudjelovanju s nepodržavajućim društvenim okruženjem nepovoljno utječu na zdravstveno ponašanje, što dovodi do negativnih zdravstvenih ishoda koji na kraju proizvode negativne učinke na motivaciju i društveno okruženje pojedinca, što zatvara krug. Prema procjeni patronažnih sestara, ispitanici u našem istraživanju često nisu primjereno prepoznavali vlastiti kardiovaskularni rizik i vrlo su nerado mijenjali svoje rizične navike. Kvantitativne analize kardiovaskularnih ponašajnih rizika snažno podupiru naše rezultate. Rezultati našeg istraživanja kardiovaskularnih ponašajnih čimbenika rizika nadopunjuju druga istraživanja kardiovaskularnih rizika koja su provedena u okviru CAHS i CroHort studija i zajedno predstavljaju širok temelj informacija za donošenje odluka za razvoj sveobuhvatnog nacionalnog programa prevencije kardiovaskularnih bolesti, koji sada može biti prilagođen u skladu s potrebama stanovništva Hrvatske. 